\title{
PENGARUH GAYA HIDUP TERHADAP MINAT BELI SMARTPHONE VIVO PADA MASYARAKAT DESA JAHARUN B DUSUN 1 KECAMATAN GALANG KABUPATEN DELI SERDANG
}

\author{
${ }^{1}$ Riska Ananda Azhhari, ${ }^{2}$ Yayuk Yuliana \\ ${ }^{1,2}$ Universitas Muslim Nusantara Al-Washliyah Medan \\ ${ }^{I}$ riska02ananda@gmail.com, ${ }^{2}$ yayuk.yuliana@gmail.com
}

\begin{abstract}
The purpose of this study was to find out how to analyze the influence of Lifestyle $(X)$ on Interest in Buying (Y) Vivo smartphones in the people of Jaharun B Village, Dusun 1, Galang District, Deli Serdang Regency with a total sample of 97 people. The data collection technique used is by using a questionnaire or questionnaire given to each respondent. The data is processed using SPSS 20. The data analysis technique used is simple linear regression (b) of 0.737 and it can be concluded that Lifestyle has a significant positive effect on Purchase Interest. Which means that if the Lifestyle is increasing, the Buying Interest will increase by 0.737. Based on the t test, it is known that tcount > ttable is 11,037 > 1,661. So it can be stated that there is a real influence between Lifestyle and Interest in Buying Vivo smartphones in the Jaharun B Village Community, Dusun 1, Galang District, Deli Serdang Regency, and the relationship is proven to be significant. From the results of the coefficient of determination ( $R$ square) it can be said that the Lifestyle variable $(X)$ has an effect on the Purchase Interest variable $(Y)$ of 0.562 or with a percentage of $56.2 \%$ and the remaining $43.8 \%$ is influenced by other variables not examined by research this.
\end{abstract}

Keywords: Lifestyle and Buying Interest

ABSTRAK : Tujuan penelitian ini adalah untuk mengetahui bagaimana menganalisis pengaruh Gaya Hidup (X) terhadap Minat Beli (Y) smartphone Vivo pada masyarakat Desa Jaharun B, Dusun 1, Kecamatan Galang, Kabupaten Deli Serdang dengan jumlah sampel sebanyak 97 orang. Teknik pengumpulan data yang digunakan adalah dengan menggunakan kuesioner atau kuesioner yang diberikan kepada setiap responden. Pengolahan data menggunakan SPSS 20. Teknik analisis data yang digunakan adalah regresi linier sederhana (b) sebesar 0,737 dan dapat disimpulkan bahwa Gaya Hidup berpengaruh positif signifikan terhadap Minat Beli. Artinya jika Gaya Hidup meningkat maka Minat Beli akan meningkat sebesar 0,737. Berdasarkan uji t diketahui bahwa thitung > ttabel yaitu $11.037>1.661$. Sehingga dapat dinyatakan bahwa terdapat pengaruh yang nyata antara Gaya Hidup dengan Minat Beli Smartphone Vivo pada Masyarakat Desa Jaharun B, Dusun 1, Kecamatan Galang, Kabupaten Deli Serdang, dan hubungan tersebut terbukti signifikan. Dari hasil koefisien determinasi ( $R$ square) dapat dikatakan bahwa variabel Gaya Hidup $(X)$ berpengaruh terhadap variabel Minat Beli $(Y)$ sebesar 0,562 atau dengan persentase sebesar $56,2 \%$ dan sisanya sebesar 43,8\% dipengaruhi oleh variabel lain yang tidak diteliti oleh penelitian ini.

Kata Kunci : Gaya Hidup and Minat Beli.

\section{Pendahuluan}

Salah satu alat bantu komunikasi tersebut adalah smartphone (telepon pintar). Smartphone adalah telepon genggam yang mempunyai kemampuan tingkat tinggi yang sudah menggunakan sistem operasi untuk menjalankan program yang ada di dalamnya. Bahkan beberapa smartphone sekarang ini sudah mempunyai fungsi yang menyerupai sebuah komputer. Hampir semua kebutuhan individu terbantu dengan smartphone, mulai dari kegiatan sehari-hari sampai yang berkaitan dengan masalah pekerjaan. Disamping fungsi utama untuk melakukan alat bertukar informasi yang cakupannya sangat luas dengan adanya jaringan internet pengguna smartphone bisa mengakses segalanya dari smartphone. Smartphone banyak menawarkan berbagai macam kelebihan segala fitur dan fungsinya yang semakin canggih seperti kamera yang 
begitu canggih dan bagus, desain yang menarik, baterai yang tahan lama dan masih banyak lagi kelebihan smartphone.

Banyaknya produk smartphone yang masuk dipasaran membuat para konsumen melakukan beberapa pertimbangan untuk memilih sebuah smartphone untuk membantu konsumen dalam melakukan kegiatan sehari-hari. Perkembangan dunia smartphone di Indonesia dari tahun ketahun terus mengalami peningkatan yang signifikan. Kebutuhan masyarakat terhadap smartphone yang semakin tinggi menjadi salah satu penyebabnya. Selain itu, hadirnya berbagai produk smartphone di Indonesia banyak menarik minat masyarakat, salah satunya yaitu smartphone merek Vivo.

Secara berurutan, pangsa pasar Smartphone di Indonesia kuartal II-2020 adalah Vivo sebesar $21.5 \%$ kemudian Oppo 20.6\%. Vivo mengalami peningkatan pangsa pasar yang signifikan dari $7.8 \%$ menjadi $21.2 \%$ pada kuartal II-2020. Vivo merupakan smartphone yang hadir dengan berbagai inovasi, contohnya yaitu kehadiran kamera tersembunyi, sensor sidik jari di dalam layar, fast charging. Smartphone merek Vivo pada umumnya hadir dengan kamera yang baik, desain yang menarik hal ini yang menjadi daya tarik konsumen. Smartphone Vivo melakukan strategi marketing dengan mengiklankan produknya diberbagai media dengan menggandeng para artis-artis ternama. Hal-hal tersebut yang membuat smartphone merek vivo cukup dikenal masyarakat luas. Contohnya seperti pada masyarakat Desa Jaharun B Dusun 1 Kecamatan Galang Kabupaten Deli Serdang.

Seiring dengan terus berkembangnya teknologi komunikasi, lingkungan pada masyarakat juga akan selalu berubah sesuai dengan perkembangan manusia itu sendiri, demikian juga halnya dengan gaya hidup. Hal ini dikaitkan dengan pemilihan smartphone, konsumen mungkin lebih memilih smartphone yang sedang trend saat ini untuk mengikuti gaya hidup. Gaya hidup seseorang akan berbeda antar masyarakat satu dengan masyarakat lainnya. Gaya hidup dapat diartikan bagaimana cara seseorang menggunakan waktu mereka (aktivitas), apa yang mereka anggap penting dalam lingkungannya dan apa yang mereka anggap penting dalam diri sendiri.

Sebagian masyarakat Desa Jaharun B Dusun 1 Kecamatan Galang Kabupaten Deli Serdang yang membeli smartphone vivo hanya untuk terlihat keren dan ingin mendapat perhatian lebih dari orang lain. Sementara itu pendapatan masyarakat pada umumnya masih UMR (Upah Minimum Regional) bahkan ada yang dibawah UMR tetapi masyarakat terlalu memaksa untuk membeli smartphone vivo tersebut agar terlihat keren dizaman sekarang ini. Masyarakat hanya menjadikan smartphone untuk gaya hidup saja, gaya hidup masyarakat yang cenderung hedonisme sehingga membuat masyarakat membeli smartphone vivo tidak sesuai dengan kebutuhannya mereka membeli ini hanya untuk kesenangan diri sendiri sehingga uang yang dipakai untuk membeli barang yang dibutuhkan pun tidak ada dan akhirnya masyarakat tersebut berhutang kepada orang lain untuk menutupi kebutuhan yang lainnya.

Biaya yang dikeluarkan menjadi tidak sesuai dengan pendapatan masyarakat. Minat beli konsumen tidak terlepas dari gaya hidup mereka yang ingin membeli sebuah produk. Keanekaragaman konsumen dalam memenuhi kebutuhannya dipengaruhi oleh karakteristik gaya hidup yaitu aktivitas seperti pekerjaan, hiburan, hobi, belanja dan pandangan terhadap produk tersebut sehingga mempengaruhi perilaku konsumen. Dengan demikian konsumen dalam memilih suatu produk akan memilih berdasarkan apa yang dibutuhkan dan sesuai dengan minat beli.

\subsection{Rumusan Masalah}

Menurut Sugiyono (2019:63), "Rumusan masalah merupakan kalimat pertanyaan yang akan dicari jawabannya melalui pengumpulan data, dimana peneliti menggunakan berbagai teori untuk menjawabnya yaitu dengan menggunakan penelitian kuantitatif".

Berdasarkan latar belakang masalah diatas, maka yang menjadi rumusan masalah penelitian ini adalah :

1) Apakah Gaya Hidup berpengaruh terhadap Minat Beli Smartphone Vivo pada Masyarakat Desa Jaharun B Dusun 1 Kecamatan Galang Kabupaten Deli Serdang?

2) Seberapa besar pengaruh Gaya Hidup terhadap Minat Beli Smartphone Vivo pada Masyarakat Desa Jaharun B Dusun 1 Kecamatan Galang Kabupaten Galang?

\subsection{Batasan Masalah}

Menurut Sugiyono (2019:32), "Batasan masalah yang dipandang penting dan berguna untuk dicarikan pemecahannya". 
Mengingat keterbatasan waktu, kemampuan, dan pengetahuan yang dimiliki penulis, maka penelitian ini dibatasi pada "Pengaruh Gaya Hidup Terhadap Minat Beli Smartphone Vivo Pada Masyarakat Desa Jaharun B Dusun 1 Kecamatan Galang".

\subsection{Tujuan Penelitian}

Menurut Sugiyono (2019:33), "Tujuan Penelitian adalah untuk menemukan, membuktikan dan mengembangkan suatu persoalan atau pengetahuan dengan menggunakan prosedur-prosedur ilmiah".

Adapun yang menjadi tujuan penelitian ini adalah :

1) Untuk mengetahui Pengaruh Gaya Hidup terhadap Minat Beli Smartphone Vivo pada Masyarakat Desa Jaharun B Dusun 1 Kecamatan Galang Kabupaten Deli Serdang.

2) Untuk mengetahui seberapa besar Pengaruh Gaya Hidup terhadap Minat Beli Smartphone Vivo pada Masyarakat Desa Jaharun B Dusun 1 Kecamatan Galang Kabupaten Deli Serdang.

\section{Metode Penelitian}

\subsection{Populasi}

Menurut Sugiyono (2019:126), "Populasi adalah wilayah generalisasi yang terdiri atau objek/subjek yang mempunyai kualitas dan karakteristik tertentu yang ditetapkan oleh peneliti untuk dipelajari dan kemudian ditarik kesimpulannya".

Berdasarkan pengertian populasi tersebut, maka yang akan menjadi populasi pada

Tabel 1. Hasil Uji Validitas

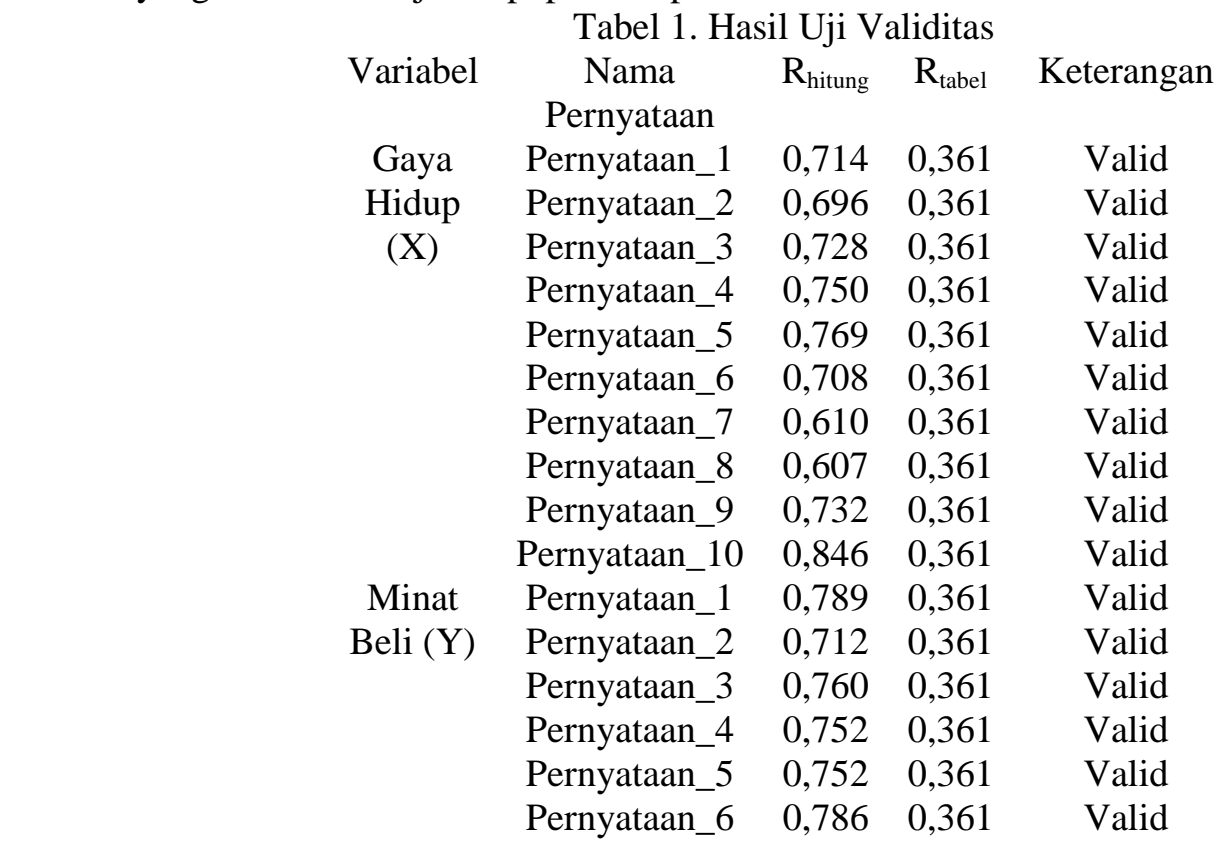

penelitian ini adalah Masyarakat Desa Jaharun B Dusun 1 Kecamatan Galang Kabupaten Deli Serdang yang menggunakan smartphone merek Vivo. Dikarenakan jumlah populasi yang menggunakan smartphone Vivo tidak di ketahui maka dalam penelitian ini belum dapat menyebutkan jumlahnya, perlu dilakukan pengambilan sampel lebih lanjut.

\subsection{Sampel}

Menurut Sugiyono (2019:127), "Sampel adalah bagian dari jumlah dan karakteristik yang dimiliki oleh populasi tersebut". Metode pengambilan sampel yang digunakan adalah sampel non probabilitas, dimana pemilihan anggota populasi menggunakan metode purposive sampling yaitu penulis menggunakan pertimbangan sendiri dengan cara sengaja dalam memilih anggota populasi yang dianggap dapat memberikan informasi yang diperlukan oleh peneliti (Sugiyono, 2019:85).

\subsection{Uji Normalitas}

\subsubsection{Uji Validitas}

Validitas adalah suatu ukuran yang menunjukkan tingkat kevalidan suatu instrumen. Uji validitas ini dilakukan dengan cara membandingkan angka $r_{\text {hitung }}$ dan $r_{\text {tabel. }}$ Jika $r_{\text {hitung }}>r_{\text {tabel }}$ maka item pernyataan dikatakan valid dan sebaliknya jika $r_{\text {hitung }}<r_{\text {tabel }}$ maka dikatakan tidak valid. Dengan jumlah sampel 30 responden diuar responden penelitian ini. Berikut ini adalah hasil uji validitas dengan menggunakan program SPSS versi 20: 


$\begin{array}{ccccc}\text { Variabel } & \begin{array}{c}\text { Nama } \\ \text { Pernyataan }\end{array} & \mathrm{R}_{\text {hitung }} & \mathrm{R}_{\text {tabel }} & \text { Keterangan } \\ \text { Pernyataan_7 } & 0,640 & 0,361 & \text { Valid } \\ \text { Pernyataan_8 } & 0,708 & 0,361 & \text { Valid } \\ \text { Pernyataan_9 } & 0,648 & 0,361 & \text { Valid } \\ \text { Pernyataan_10 } & 0,760 & 0,361 & \text { Valid }\end{array}$

Berdasarkan hasil perhitungan menggunakan SPSS diatas menunjukkan bahwa variabel Gaya Hidup (X) pada pernyataan 1 hasil $r_{\text {hitung }}$ $(0,714)$, pernyataan 2 hasil $r_{\text {hitung }}(0,696)$, pernyataan 3 hasil $r_{\text {hitung }}(0,728)$, pernyataan 4 hasil $\mathrm{r}_{\text {hitung }}(0,750)$, pernyataan 5 hasil $\mathrm{r}_{\text {hitung }}$ $(0,769)$, pernyataan 6 hasil $r_{\text {hitung }}(0,708)$, pernyataan 7 hasil $r_{\text {hitung }}(0,610)$, pernyataan 8 hasil $r_{\text {hitung }}(0,607)$, pernyataan 9 hasil $r_{\text {hitung }}$ $(0,732)$, pernyataan 10 hasil $\mathrm{r}_{\text {hitung }}(0,846)$.

Variabel Minat Beli (Y) pada pernyataan 1 hasil $\mathrm{r}_{\text {hitung }}(0,789)$, pernyataan 2 hasil $\mathrm{r}_{\text {hitung }}$ $(0,712)$, pernyataan 3 hasil $r_{\text {hitung }}(0,760)$, pernyataan 4 hasil $r_{\text {hitung }}(0,752)$, pernyataan 5 hasil $\mathrm{r}_{\text {hitung }}(0,752)$, pernyataan 6 hasil $\mathrm{r}_{\text {hitung }}$ $(0,786)$, pernyataan 7 hasil $r_{\text {hitung }}(0,640)$, pernyataan 8 hasil $r_{\text {hitung }}(0,708)$, pernyataan 9 hasil $\mathrm{r}_{\text {hitung }}(0,648)$, pernyataan 10 hasil $\mathrm{r}_{\text {hitung }}$ $(0,760)$ dinyatakan valid, dilihat pada tabel product moment, dengan $\mathrm{n}=30$, dan taraf kesalahan 0,05 atau 5\% maka diperoleh $\mathrm{r}_{\text {tabel }}=$

0,361 ternyata $r_{\text {hitung }}$ item dari setiap pernyataan lebih besar dari $r_{\text {tabel }}$ dengan demikian dapat dinyatakan signifikan atau valid.

\title{
2.3.2. Uji Reliabilitas
}

Uji reliabilitas metode pengujian yang digunakan untuk melihat apakah instrumen penelitian merupakan instrumen yang dapat dipercaya. Jika variabel penelitian menggunakan instrumen yang dapat dipercaya maka hasil penelitian juga memiliki tingkat kepercayaan yang tinggi. Teknik yang digunakan untuk mengukur tingkat reliabilitas adalah Cronbath Alpha. Apabila nilai Cronbath Alpha diatas 0,6 maka instrumen tersebut dikatakan reliabel. Pada uji reliabilitas dilakukan dengan menggunakan program SPSS versi 20. Untuk jumlah sampel yang diambil pada penelitian ini berjumlah 30 responden diluar responden penelitian ini.

\section{Tabel 2. Hasil Uji Reliabilitas}

Variabel

Gaya Hidup (X)

Cronbach's Alpha

Minat Beli (Y)

0,894

0,902

(Sumber : Pengolahan data menggunakan SPSS 20, 2021)

Berdasarkan hasil uji reliabilitas diatas, diketahui bahwa seluruh instrumen yang digunakan dalam penelitian ini adalah realibel, yang ditunjukkan dengan nilai dari masingmasing instrumen memiliki nilai lebih besar dari 0,6 .

\section{Hasil Dan Pembahasan}

\subsection{Analisis Regresi Linear Berganda}

\author{
Keterangan \\ Reliabel \\ Reliabel
}

Analisis ini digunakan untuk mengetahui Pengaruh Gaya Hidup Terhadap Minat Beli Smartphone Vivo Pada Masyarakat Desa Jaharun B Dusun I Kecamatan Galang Kabupaten

Deli Serdang, dimana mejadi variabel bebasnya Gaya Hidup (X) dan variabel terikatnya Minat Beli (Y), maka digunakan analisis regresi linier sederhana.

Tabel 3. Hasil Uji Regresi Linier Sederhana

\begin{tabular}{|c|c|c|c|c|c|}
\hline \multicolumn{6}{|c|}{ Coefficients $^{\mathrm{a}}$} \\
\hline \multirow[t]{2}{*}{ Model } & \multicolumn{2}{|c|}{$\begin{array}{l}\text { Unstandardized } \\
\text { Coefficients }\end{array}$} & \multirow{2}{*}{$\begin{array}{l}\text { Standardized } \\
\text { Coefficients } \\
\text { Beta }\end{array}$} & \multirow[t]{2}{*}{$\mathrm{t}$} & \multirow[t]{2}{*}{ Sig. } \\
\hline & B & Std. Error & & & \\
\hline \multirow[t]{2}{*}{1 Constant } & 12,607 & 2,237 & & 5,636 & 0,000 \\
\hline & 0,737 & 0,067 & 0,750 & 11,037 & 0,000 \\
\hline
\end{tabular}

Sumber : Hasil Peneliti 2021. 
Dari tabel tersebut diketahui persamaan regresi linear sederhana antara variabel independen dan variabel dependen sebagai berikut :

$$
\mathrm{Y}=12,607+0,737 \mathrm{X}+\mathrm{e}
$$

Dari persamaan regresi tersebut dapat disimpulkan bahwa:

1) Konstanta (a) $=12,607$ artinya jika variabel Gaya Hidup bernilai 0 maka Minat Beli pada Masyarakat Desa Jaharun B Dusun 1 Kecamatan Galang Kabupaten Deli Sedang adalah sebesar 12,607.

2) Koefisien regresi variabel Gaya Hidup = 0,737 artinya jika variabel Gaya Hidup meningkat sebesar 1 satuan maka variabel Minat Beli akan meningkat 0,737.

\subsection{Uji Hipotesis (Uji t)}

Uji t bertujuan untuk menunjukkan seberapa jauh pengaruh variabel independen terhadap variabel dependen. Selain itu, uji t adalah uji yang dilakukan untuk membuktikan hipotesis awal yaitu Gaya Hidup berpengaruh signifikan terhadap Minat Beli Smartphone Vivo Pada Masyarakat Desa Jaharun B Dusun I Kecamatan Galang Kabupaten Deli Serdang.

Tabel 4. Hasil Uji T Parsial (Uji t)

\begin{tabular}{|c|c|c|c|c|c|}
\hline \multicolumn{6}{|c|}{ Coefficients $^{\mathrm{a}}$} \\
\hline \multirow[t]{2}{*}{ Model } & \multicolumn{2}{|c|}{$\begin{array}{l}\text { Unstandardized } \\
\text { Coefficients }\end{array}$} & $\begin{array}{l}\text { Standardized } \\
\text { Coefficients }\end{array}$ & \multirow[t]{2}{*}{$\mathrm{t}$} & \multirow[t]{2}{*}{ Sig. } \\
\hline & B & Std. Error & Beta & & \\
\hline \multirow[t]{2}{*}{1 Constant } & 12,607 & 2,237 & & 5,636 & 0,000 \\
\hline & 0,737 & 0,067 & 0,750 & 11,037 & 0,000 \\
\hline
\end{tabular}

Sumber : Hasil Peneliti 2021.

Berdasarkan hasil dari tabel 5. maka diperoleh nilai $t_{\text {hitung }}=11,037$ sedangkan nilai $\mathrm{t}_{\text {tabel }} \mathrm{df}=\mathrm{n}-2 \quad(\mathrm{df}=97-2=95)$ pada taraf signifikan $5 \%(0,05)$, adalah 1,661 dan jika $t_{\text {hitung }}>t_{\text {tabel }}$ maka hipotesis (Ha) diterima, maka dari perhitungan diatas dapat diketahui bahwa $t_{\text {hitung }}>t_{\text {tabel }}$ yaitu $11,037>1,661$. sehingga dapat dinyatakan bahwa terdapat pengaruh yang nyata antara Gaya Hidup terhadap Minat Beli Smartphone Vivo Pada Masyarakat Desa Jaharun B Dusun I Kecamatan Galang

Kabupaten Deli Serdang dan hubungan terbukti signifikan.

\subsection{Koefisien Determinasi (R Square)}

Uji determinasi dilakukan untuk mengetahui seberapa besar Pengaruh Gaya Hidup terhadap Minat Beli Smartphone Vivo Pada Masyarakat Desa Jaharun B Dusun I Kecamatan

Galang Kabupaten Deli Serdang. Uji determinasi dilakukan dengan menggunakan program SPSS versi 20. Hasil uji determinasi dapat dilihat pada tabel dibawah ini.

Tabel 5. Hasil Koefisien Determinasi (R Square)

\begin{tabular}{|c|c|c|c|c|}
\hline \multicolumn{5}{|c|}{ Model Summary $^{\mathbf{b}}$} \\
\hline Model & $\mathrm{R}$ & $\mathrm{R}$ Square & $\begin{array}{c}\text { Adjusted R } \\
\text { Square }\end{array}$ & $\begin{array}{c}\text { Std. Error of } \\
\text { the Estimate }\end{array}$ \\
\hline 1 & 0,750 & 0,562 & 0,557 & 3,567 \\
\hline
\end{tabular}

(Sumber : Pengolahan data menggunakan SPSS 20, 2021)

Dari perhitungan tersebut dapat dikatakan bahwa variabel Gaya Hidup (X) berpengaruh terhadap variabel Minat Beli (Y) sebesar 0,562 atau dengan persentase $56,2 \%$ dan sisanya $43,8 \%$ dipengaruhi oleh variabel lain diluar penelitian ini.

\section{Hasil Analisa}

Penelitian ini bertujuan untuk mengetahui apakah ada Pengaruh Gaya Hidup Terhadap Minat Beli Smartphone Vivo Pada Masyarakat Desa Jaharun B Dusun 1 Kecamatan Galang
Kabupaten Deli Serdang. Dalam penelitian ini penulis menggunakan Analisis Data Kuantitatif deskriptif dengan jumlah sampel 97 orang dengan menggunakan purposive sampling. Penelitian ini digunakan dengan cara membagikan kuesioner kepada masyarakat Desa Jaharun B Dusun 1 Kecamatan Galang Kabupaten Deli Serdang. Untuk mengetahui hasil penelitian penulis menggunakan rumus Lemeshow, Analisis Regresi Liner Sederhana, Uji Validitas, Uji Reliabilitas, Uji Normalitas, Uji t dan Uji Koefisien Determinasi (R2). Dari 
hasil penelitian yang dilakukan, maka dapat diketahui bahwa Gaya Hidup (X) memiliki pengaruh yang positif dan signifikan terhadap Minat Beli (Y).

Berdasarkan hasil penelitian yang dilakukan, dari variabel yang digunakan terbukti mempunyai pengaruh positif dan signifikan. Dari perhitungan dengan uji $\mathrm{t}$ diperoleh $\mathrm{t}_{\text {hitung }}$ $(11,037)>t_{\text {tabel }}(1,661)$ sedangkan nilai signifikan sebesar 0.000 dapat diartikan bahwa Ho ditolak Ha diterima, yang menyatakan bahwa Gaya Hidup mempunyai pengaruh terhadap Minat Beli Smartphone Vivo Pada Masyarakat Desa Jaharun B Dusun I Kecamatan Galang Kabupaten Deli Serdang. Pengaruh ini menunjukkan bahwa semakin baik persepsi responden mengenai Gaya Hidup telah berhasil meingkatkan Minat Beli.

Besarnya hubungan antara Gaya Hidup terhadap Minat Beli Smartphone Vivo Pada Masyarakat Desa Jaharun B Dusun I Kecamatan Galang Kabupaten Deli Serdang adalah 56,2\%. Hal ini berarti bahwa Minat Beli Smartphone Vivo dipengaruhi oleh Gaya Hidup sebesar $56,2 \%$. Sedangkan sisanya dipengaruhi oleh faktor-faktor lain diluar dari penelitian ini sebesar 43,8\%, sehingga dapat dinyatakan bahwa Gaya Hidup berpengaruh terhadap Minat Beli Smartphone Vivo Pada Masyarakat Desa Jaharun B Dusun I Kecamatan Galang Kabupaten Deli Serdang.

Hasil Penelitian juga selaras dengan penelitian terdahulu yaitu pada penelitian yang relevan diantaranya penelitian Kamaluddin 2018, Rizal Nur Irawan 2020, Dita Muhajjirin 2020, Putu Febryanta 2019, Seprianto 2018, Pallavi Chugh 2020, dan Eka Dewi Setia 2020.

\section{Kesimpulan}

1) Berdasarkan hasil regresi linier sederhana maka dapat diketahui seberapa besar pengaruh variabel Gaya Hidup (X) dengan Minat Beli (Y), ini menunjukkan bahwa konstanta (a) sebesar 12,607 sedangkan koefisien regresi sederhana (b) sebesar 0,737 dan dapat disimpulkan bahwa Gaya Hidup mempunyai pengaruh yang positif terhadap Minat Beli. Yang artinya apabila Gaya Hidup meningkat, maka Minat Beli akan mengalami kenaikan sebesar 0,737.

2) Dari hasil analisis uji t, maka diperoleh nilai $\mathrm{t}_{\text {hitung }}=11,037$ sedangkan nilai $\mathrm{t}_{\text {tabel }} \mathrm{df}=\mathrm{n}-2$ $(\mathrm{df}=97-2=95)$ pada taraf signifikan $5 \%$ $(0,05)$, adalah 1,661 dan jika $t_{\text {hitung }}>t_{\text {tabel }}$ maka hipotesis (Ha) diterima, maka dari perhitungan diatas dapat dinyatakan bahwa $t_{\text {hitung }}>t_{\text {tabel }}$ yaitu 11,037>1,661 Sehingga dapat dinyatakan bahwa terdapat pengaruh yang nyata antara Gaya Hidup terhadap Minat Beli Smartphone Vivo Pada Masyarakat Desa Jaharun B Dusun I Kecamatan Galang Kabupaten Deli Serdang dan hubungan tersebut terbukti signifikan.

3) Dari perhitungan uji determinasi dapat dikatakan bahwa variabel Gaya Hidup (X) berpengaruh terhadap variabel Minat Beli (Y) sebesar 0,562 atau dengan persentase $56,2 \%$ dan sisanya $43,8 \%$ dipengaruhi oleh variabel lain yang tidak diteliti oleh penelitian ini.

4) Berdasarkan hasil uji yang telah dilakukan peneliti, maka dapat disimpulkan bahwa hasil pengujian keseluruhan telah terbukti nyata bahwa benar adanya Pengaruh Gaya Hidup Terhadap Minat Beli Smartphone Vivo Pada Masyarakat Desa Jaharun B Dusun I Kecamatan Galang Kabupaten Deli Serdang.

\section{DAFTAR PUSTAKA}

Arikunto, Suharsimi. 2017. Prosedur Penelitian Suatu Pendekatan Praktik. Jakarta: Rineka Cipta.

Cugh, Pallavi. 2020. "Effect of Values and Life Style on Consumer Online Purchase Intention". Mukt Shabd Journal. 9, (6), 1965-1969.

Dita, Muhajirin. 2020. "Pengaruh Sales Promotion Girl Smartphone Vivo Terhadap Minat Beli Konsumen di Kota Bima”. Jurnal of Business and Economics Research (JBE). 1, (2), 110-114.

Kamaluddin, Muhajjirin. 2018. "Pengaruh Gaya Hidup Terhadap Minat Beli Konsumen Dalam Berbelanja Online". Jurnal Akrab Juara. 3, (3), 113-122.

Irawan Nur, Rizal. 2020. "Pengaruh Kualitas Produk, Harga Dan Promosi Terhadap Minat Beli Konsumen Pada PT.Satria Nusantara Jaya". Jurnal Ekonomi Universitas Kadiri. 05, (2), 141-153.

Febryantha, Putu. 2019. "Peran Sikap Dalam Memediasi Pengaruh Gaya Hidup Terhadap Minat Beli Smartphone Iphone di kota Denpasar". E-Jurnal Manajemen Unud. 08, (3), 1487-1514.

Priansa, Donni Juni. 2020. Perilaku Konsumen dalam persaingan bisnis kontemporer. Bandung: Alfabeta. 
Seprianto, 2018. "Pengaruh Gaya Hidup, Fitur, dan Promosi Terhadap Keputusan Pembelian Oppo Smartphone di Kota Padang”. Jurnal Marketing. 01, (1), 68-74.

Setia, Eka Dewi, at all. 2020. "The Influence of Lifestyle and Sales Promotion on Online Purchase Decisions for Home-Cooked Culinary during COVID-19 in Medan City Indonesia". International Journal of Research and Review. 7, (10), 140-144.
Sugiyono. 2019.Metode Penelitian Kuantitatif, Kualitatif, dan R\&D. Bandung: Alfabeta. Sugiyono. 2018.Metode Penelitian Kuantitatif, Kualitatif, dan R\&D. Bandung: Alfabeta. Yuniarti S, Vinna, 2015. Perilaku Konsumen. Bandung: Pustaka Setia.

https://tekno.kompas.com/read/2020/09/07/10 072907/5-besar-vendor-ponsel-diindonesia-kuartal-ii-2020-oppo-dan-vivogeser-samsung 